\title{
ANALYSIS ON THE LEVEL OF PHYSICAL WORKLOAD OF COAL HANDLING CONTROL ROOM AND SHIP UNLOADER OPERATION IN CILACAP STEAM TURBINE POWER PLANT
}

\author{
Wahyu Ismail Kurnia*)1, Muhammad Isradi Zainal'), Alex Kisanjani*) \\ *) Department of Industrial Engineering, Faculty of Industrial Technology, Universitas Balikpapan \\ Jl. Pupuk Raya, Kel. Gunung Bahagia, Kec. Balikpapan Selatan, Balikpapan 76114 Indonesia
}

\begin{abstract}
The company mentions the frequent inaccuracies between coal unloading data on barges with coal availability in coal silos and stock piles carried out by Coal handling Control Room (CHCR) operators. Moreover, unloading coal on barges by Ship Unloader (SU) operators took a longer time than the specified estimated time. Therefore, this study aims to investigate whether the physical workloads of CHCR and SU operators are heavy and cause fatigue, which eventually causes a number of problems that lead to company losses, or whether the cause of these problems is not in operator's physical workload. This study involved 16 CHCR and SU operators with 3 work shifts. Physical workload measurement is referred on operator's pulse and temperature. Pulse measurement is manually done to both working and resting operators. Meanwhile, body temperature measurement is done before, when, and after working by using digital thermometer. Cardiovascular Load (CVL) approach is used to check pulses, to find out whether the workload is considered as heavy or light, while body temperature is referred to indicators or normal temperature range. The results of pulse measurements were processed and analyzed using the Cardiovascular Load (CVL) approach. Then, body temperature measurement is carried out to the operator's before work, during work, and after work using a thermometer. The results show that the physical workload of CHCR and SU operators are classified as light and do not potentially lead them to work fatigue. In other words, the source of company's problems is not from physical workloads of CHCR and SU operator but likely from other aspects.
\end{abstract}

Keywords: body temperature, cardiovascular load, operator, physical workload, pulse rate

\begin{abstract}
Abstrak: Pihak perusahaan menyebutkan bahwa sering terjadi kesalahan pencatatan atas data pembongkaran batubara di kapal tongkang dengan ketersediaan batubara di coal silo dan stock pile yang dilakukan oleh operator Coal handling Control Room (CHCR) dan pembongkaran batubara di kapal tongkang oleh operator Ship Unloader (SU) membutuhkan waktu lebih lama dari estimasi waktu yang ditentukan. Penelitian ini bertujuan menyelidiki apakah beban kerja fisik operator CHCR dan SU tergolong berat dan mengakibatkan operator mudah lelah yang pada akhirnya menimbulkan sejumlah permasalahan yang berunjung kepada kerugian perusahaan atau penyebab permasalahan tersebut bukan bersumber dari beban kerja secara fisik operator. Penelitian ini melibatkan seluruh operator CHCR dan SU yang berjumlah 16 orang dengan 3 shift kerja. Pengukuran beban kerja secara fisik berdasarakan denyut nadi dan suhu tubuh operator. Pengukuran denyut nadi dilakukan secara manual terhadap operator yang sedang bekerja dan beristirahat. Sementara, pengukuran suhu tubuh dilakukan ketika operator sebelum, sedang dan setelah bekerja dengan menggunakan digital thermometer. Untuk mengetahui beban kerja tergolong berat atau tidak berdasarkan denyut nadi digunakan pendekatan Cardiovascular Load (CVL). Sementara suhu tubuh berdasarkan indikator atau range. Hasil penelitian menunjukan bahwa beban kerja secara fisik operator CHCR dan SU tergolong ringan dan tidak berpotensi menimbulkan kelelahan kerja. Dengan kata lain, permasalahan perusahaan bukan bersumber dari beban kerja operator CHCR dan SU secara fisik tetapi mungkin bersumber dari aspek lain.
\end{abstract}

Kata kunci: suhu tubuh, cardiovascular load, operator, beban kerja fisik, denyut nadi

\footnotetext{
${ }^{1}$ Alamat Korespondensi:

Email: wahyu.ismail.kurnia@uniba-bpn.ac.id
} 


\section{INTRODUCTION}

The depiction of a corporation system is economically valuable and can be used in form of finished product which going through a series of transformational processes driven by human as the designer as well as the driving force in either internal or external activities. The success of a corporation system highly depends on the composition subsystem which interacted each other and show a good performance (Rusnock and Borghetti, 2018). In a company system, human cannot avoid the subsystem as the composition of the system itself, because human is the important factor in the success of a company system performance (Jex, 1998; LePine et al. 2005; Kahya, 2007; Balfe et al. 2015; Rusnock and Borghetti, 2018). In the context of manufacturing company, repetition activities are inevitable, and human is the one who run the task. In running the task, the potential of error might arises and affects the safety of operator and working environments (Bommer and Fendley, 2018). As known, operators tend to have high levels of variability and low levels of reliability (Rusnock and Borghetti, 2018) and affected by various things, such as quick decision making, information accuracy, punctuality, and work station layout (Lindblom and Thorvald, 2014). The potential for errors will be greater if the operator is not thorough in their work, or when their workload is excessive.

The manufacturing industry always tries as much as possible to use human operators in order to carry out a number of large and complex task (Schor, 1991). A non-optimal workload design can affects operator performance and condition. The tasks carried out by operators that become more complex followed by workloads that become heavier will likely affect their physical and mental conditions (Vidulich and Tsang, 2015).

In accordance with the research of Madeleine (2010); Horton et al. (2015); Ivarsson and Eek (2016), excessive workloads may trigger operators' excessive force, which in turn made them easily experience physical fatigue and affect their work performance as well. Moreover, when they often exposed to heat pressure in working area, the risk of accidents might increase, and their productivity at work might be reduced (Hassan et al. 2017; Tustin et al. 2018). Meanwhile, operator's error is the dominant factor of working accident in industrial environment with the contribution reaching 70\%-90\% (Isaac et al. 2002; Yan et al. 2017). Failure in distributing the workload, resulting in ineffective and inefficient way of doing the work, has become one of the triggers of industrial accidents. Therefore, it is necessary to pay attention to the working systems and workloads that prioritize worker's safety and convenience in order to minimize the accidents.

Cilacap Steam-Power Plant is a company that supplies electrical energy in Central Java area. This company uses coal as raw material, which is transformed into electrical energy. The in-charge section to handle raw materials at the company is the Coal Handling System. In this section, the operators must operate two belt conveyors and chute transfer towers, ensure the coal to fill-up to the maximum level, unload coals, then do structuring, recording, and reporting on each coal unloading to filling, starting from barges, filling in coal silos and stockpile until the coal burning process takes place. Operators monitor a number of activities and equipment operation processes through two computer units throughout 24 hours. To reduce work accidents especially physical fatigue experienced by operators, 4 groups were formed (13 people per group) with 3 work shifts (08.00-16.00;16.00-24.00; and 24.00-08.00). However, reports from the company stated that frequent errors or inaccuracies still happened in recording data between coal unloading on barges with the availability of coal in coal silos and stock piles, which carried out by Coal Handling Control Room (CHCR) operators. Furthermore, sometimes CHCR operators were slow in reporting coal stocks that had reached the maximum level to the Maximo system through two computers. It resulted in the increasing number of costs, such as the overtime wage for operator, the costs for resting barge at the port, and the cost for additional supporting personnel.

On the other hand, CHCR operators who worked in the third shift (24.00-08.00) said that the errors occurred were caused by fatigue they sometimes experienced at work, such as low back pain, sore hands, and tired eyes. The conditions resulted in loss of concentration during recording and monitoring. It was all based on the work of operators who were required to be continuously on standby in front of the computer, to monitor coal's path until it reached stock pile and coal silo. A number of operators complained about the fatigue they had experienced during work time, particularly at night. Still from the same section, the data obtained mentioned the unloading time of coal on a barge with a capacity of 8,000 tons by the Ship Unloader (SU) operator took 
more than 20 hours/day, and a barge with a capacity of 10,000 tons took more than 24 hours. As a result, there had been an inevitable increases in the number of costs as well as abnormal operating conditions and equipment damage caused by operators' negligence. It resulted in substantial losses for the company in 2019. SU operators who worked in shifts 2 and 3 said that they sometimes got tired and lost concentration when unloading coal using stacker reclaimer. The results were a lot of wasted time and missed time calculation in coal unloading process from barges and the coal moving process to stock piles .

The aim of this study is to find out whether the workload of CHCR and SU's operators is considered physically heavy which leading to work fatigue symptoms and caused a number of problems that resulted in company losses, or in the contrary, whether the workload is actually light and does not cause fatigue to operators. To verify the problems, physical workload measurement was carried out for all CHCR and SU operators in three work shifts; before work, at work, and after work, through manual pulse measurement and body temperature measurement using a digital thermometer (Grandjean, 1988; Nurmianto (1996). Cardiovascular Load (CVL) approach was used to determine whether the workload was heavy or not based on pulse (Tarwaka et al. 2004). Meanwhile, body temperature was referred to indicator or normal temperature range (Levander et al. 2002; Christensen at al. 1991).

\section{METHODS}

This research was conducted in Coal Handling System division of Cilacap Steam-Power Plant, Central Java, from May 2019 to August 2019. The main raw material used to produce electrical energy by Cilacap SteamPower Plant is coal. It is known that the electrical energy generated by Cilacap Steam-Power Plant can reach $2 \times 300 \mathrm{MW}$ which is connected to the networks along Java, Madura, and Bali.

This study uses descriptive approach, in which the results of physical operator workload measurements are elaborated and then analyzed, so that the operators who are experiencing overload working as well as the highest and lowest level of fatigue can be discovered. The object of this research is the measurement of operator workload in the Coal Handling System of Cilacap power plant. The subjects of this study were
Coal Handling Control Room (CHCR) and Ship Unloader (SU) operators, consisting of 8 CHCR and $8 \mathrm{SU}$ operators who are working in 3 shifts, which are night, morning, and afternoon shifts.

The research data used for this study consisted of primary and secondary data. Primary data were obtained by conducting interviews, field observations, and direct measurements of physical workload of operators by using pulse rate and body temperature. According to Nurmianto (1996), the weight of workload whether the works are heavy or not can be measured by pulse rate and body temperature. This is similar with the statement which mentions that pulse rate and body temperature are equal with the work being done (Grandjean, 1988). The measurements consisted of their pulse rate and body temperature in 3 working shifts. Pulse rate measurement was done manually, when the operator was both in work and break time. Counting pulse rate is known to be no less accurate than calculating heart rate.In addition, there are several advantages of counting pulse rate compared to calculating heart rate. It is easier, faster, cheap, and does not require expensive sophisticated equipment, as well as not interfere subject's working activities (Mutia, 2016).

Meanwhile, body temperature measurement were carried out by using a thermometer. It was done to the operators before work, at work and after work. Furthermore, secondary data used were consisted of literature reviews, scientific journal, internet-based data, and personal data (job descriptions) of operators who worked in Cilacap power plant, particularly from the division of Coal Handling System.

Data processing was done after collecting primary and secondary data. There were three stages in this step: (1) Classified the result of operator's pulse rate measurement in work and break time based on each working shifts. From the data, the level of operators workload was measured, including heavy workloads which whether could generate fatigue or not. The measurement was done using Cardiovascular Load (CVL). Besides pulse rate calculation, operator's age also used as the determiner for maximum sum of pulse rate and the scale of CVL value percentage (Tarwaka et al. 2004). Meanwhile, the results of measurement and calculation of \% CVL are divided into several categories, as in table 1 . The calculation of CVL value was done by using the formula below (Manuaba, 1998). (2) Classified the results of operator's body temperature 
measurements before work, at work and after work. The average value was calculated from the classification result of operator's body temperature to find out whether their body temperature could be categorized as normal or not. A good workload and supportive work environment were known to make operators feel comfortable during working (Manuaba, 1998). The determiner for operator's body temperature category could be seen in Table 2 (Christensen and Christensen, 1991; Sund-Levander, 2002). (3) Conducted analysis and proposed improvements of physical workload for operators who experienced fatigue at work which calculated based on the percentage of CVL values and body temperature which classified as higher than normal along with workload balance that categorized as exceeded the standard.

$\% \mathrm{CVL}=(100 \times($ Working pulse - Resting pulse $)) /$ (Maximum pulse - Resting pulse)

Maximum pulse rate for male $=220-$ Age

Maximum pulse rate for female $=200-$ Age

Table 1. Category of CVL

\begin{tabular}{cl}
\hline Value of CVL $(\%)$ & \multicolumn{1}{c}{ Category } \\
\hline$<30$ & Fatigue does not occur \\
$31-60$ & Improvement is needed \\
$61-80$ & Worked in a short time \\
$81-100$ & Immediate action is needed \\
$>100$ & Not allowed to move \\
\hline
\end{tabular}

Table 2. Workload category based on body temperature

\begin{tabular}{cc}
\hline Body Temperature & Workload Category \\
\hline$<37.5^{\circ} \mathrm{C}$ & Light \\
$37.5^{\circ} \mathrm{C}-38.0^{\circ} \mathrm{C}$ & Average \\
$38.0^{\circ} \mathrm{C}-38.5^{\circ} \mathrm{C}$ & Heavy \\
$38.5^{\circ} \mathrm{C}-90.0^{\circ} \mathrm{C}$ & Very heavy \\
$>90.0^{\circ} \mathrm{C}$ & Extremely heavy \\
\hline
\end{tabular}

\section{RESULTS}

In this part, the processing and analyzing of Coal handling Control Room (CHCR) and Ship Unloader (SU) operator's physical workload data were determined from the results of the operator's pulse rate and body temperature measurements. The pulse rate was measured when the operator was in work and break time, which aimed to determine to what extent that the workload given by the company did not cause negative effect on the operator, or in what level of workload that could cause physical fatigue on operators.

\section{Operator's Pulse Rate}

This sub-chapter presents the physical measurement results of CHCR and SU operators' workload, by checking on pulse. Pulse measurement was done manually, directly when the operator was working and resting. From the measurement results which calculated using Cardiovascular Load (CVL) approach, the workload will be verified, resulted in which operator division that classified as light, medium, heavy, very heavy or extremely heavy. The measurement results are presented in Table 3.

\section{Operator's Body Temperature}

Following the pulse measurement stage, operators were asked to measure their body temperature at before work, during work, and after work. Using a thermometer, measurements were carried out directly toward all CHCR and SU operators who work in the morning, evening and night shift. The results of operator's temperature measurements are shown in Table 4

\section{Operator's Pulse Rate}

The result in Table 3 showed that the workload of 8 operators in each CHCR and SU according to the result of CVL value percentage was less than $30 \%$, meant that all operators did not experience fatigue in doing their work. Furthermore, we could see from the average pulse of working operator was at $86.44 \%$ or less than $100 \%$, meant that the workload experienced by the operator could be categorized as light (Christensen and Christensen, 1991). The result shows that Cilacap power plant has been able and success in distributing proportional workload for the operators and take the factors that can generate fatigue in working time both internal and external factors into account (Tarwaka et al. 2004). 
Table 3. The result of measurement and calculation of operator's pulse rate

\begin{tabular}{|c|c|c|c|c|c|c|c|c|c|}
\hline \multirow[t]{2}{*}{ Position } & \multirow{2}{*}{$\begin{array}{l}\text { Years of } \\
\text { Service }\end{array}$} & \multirow[t]{2}{*}{ Sex } & \multirow{2}{*}{$\begin{array}{c}\text { Age } \\
\text { (years) }\end{array}$} & \multirow[t]{2}{*}{ Shift } & \multicolumn{2}{|c|}{ Pulse rate (pulse/mins) } & \multirow{2}{*}{$\begin{array}{l}\text { Pulse } \\
\text { Rate }\end{array}$} & \multirow[t]{2}{*}{ CVL } & \multirow[t]{2}{*}{ Result } \\
\hline & & & & & Break & Work Time & & & \\
\hline \multirow[t]{3}{*}{ 1st CHCR Op } & 9 & Male & 29 & Night & 59 & 76 & & 15.18 & No fatigue occurred \\
\hline & & & & Morning & 69 & 81 & 171 & 11.76 & No fatigue occurred \\
\hline & & & & Afternoon & 65 & 77 & & 11.32 & No fatigue occurred \\
\hline \multirow[t]{3}{*}{ 2nd CHCR Op } & 3 & Male & 29 & Night & 60 & 69 & & 6.87 & No fatigue occurred \\
\hline & & & & Morning & 65 & 71 & 191 & 4.76 & No fatigue occurred \\
\hline & & & & Afternoon & 64 & 70 & & 4.72 & No fatigue occurred \\
\hline \multirow[t]{3}{*}{ 3rd CHCR Op } & 9 & Male & 29 & Night & 58 & 86 & & 21.05 & No fatigue occurred \\
\hline & & & & Morning & 67 & 73 & 191 & 4.84 & No fatigue occurred \\
\hline & & & & Afternoon & 63 & 75 & & 9.38 & No fatigue occurred \\
\hline \multirow[t]{3}{*}{ 4th CHCR Op } & 7 & Male & 27 & Night & 72 & 97 & & 20.66 & No fatigue occurred \\
\hline & & & & Morning & 81 & 108 & 166 & 24.11 & No fatigue occurred \\
\hline & & & & Afternoon & 70 & 78 & & 6.5 & No fatigue occurred \\
\hline \multirow[t]{3}{*}{ 5th CHCR Op } & 8 & Male & 31 & Night & 57 & 69 & & 9.09 & No fatigue occurred \\
\hline & & & & Morning & 62 & 71 & 189 & 7.09 & No fatigue occurred \\
\hline & & & & Afternoon & 64 & 72 & & 6.4 & No fatigue occurred \\
\hline \multirow[t]{3}{*}{ 6th CHCR Op } & 6 & Male & 28 & Night & 60 & 69 & & 6.82 & No fatigue occurred \\
\hline & & & & Morning & 64 & 70 & 192 & 4.69 & No fatigue occurred \\
\hline & & & & Afternoon & 65 & 71 & & 4.72 & No fatigue occurred \\
\hline \multirow[t]{3}{*}{ 7th CHCR Op } & 9 & Male & 29 & Night & 72 & 92 & & 16.81 & No fatigue occurred \\
\hline & & & & Morning & 74 & 95 & 191 & 17.95 & No fatigue occurred \\
\hline & & & & Afternoon & 75 & 94 & & 16.38 & No fatigue occurred \\
\hline \multirow[t]{3}{*}{ 8th CHCR Op } & 7 & Male & 29 & Night & 75 & 78 & & 2.59 & No fatigue occurred \\
\hline & & & & Morning & 76 & 92 & 166 & 13.91 & No fatigue occurred \\
\hline & & & & Afternoon & 85 & 92 & & 6.6 & No fatigue occurred \\
\hline \multirow[t]{3}{*}{ 1st SU Op } & 11 & Male & 59 & Night & 69 & 80 & & 11.96 & No fatigue occurred \\
\hline & & & & Morning & 64 & 68 & 169 & 4.12 & No fatigue occurred \\
\hline & & & & Afternoon & 96 & 109 & & 20 & No fatigue occurred \\
\hline \multirow[t]{3}{*}{ 2nd SU Op } & 11 & Male & 36 & Night & 67 & 89 & & 18.8 & No fatigue occurred \\
\hline & & & & Morning & 78 & 96 & 189 & 16.98 & No fatigue occurred \\
\hline & & & & Afternoon & 76 & 101 & & 23.15 & No fatigue occurred \\
\hline 3rd SU Op & 11 & Male & 39 & Night & 72 & 97 & & 22.94 & No fatigue occurred \\
\hline & & & & Morning & 81 & 108 & 189 & 27 & No fatigue occurred \\
\hline & & & & Afternoon & 70 & 78 & & 7.21 & No fatigue occurred \\
\hline 4th SU Op & 10 & Male & 44 & Night & 77 & 92 & & 15.15 & No fatigue occurred \\
\hline & & & & Morning & 72 & 97 & 182 & 24.04 & No fatigue occurred \\
\hline & & & & Afternoon & 76 & 91 & & 15 & No fatigue occurred \\
\hline 5th SU Op & 10 & Male & 31 & Night & 64 & 97 & & 26.4 & No fatigue occurred \\
\hline & & & & Morning & 82 & 102 & 189 & 18.69 & No fatigue occurred \\
\hline & & & & Afternoon & 95 & 97 & & 2.13 & No fatigue occurred \\
\hline 6th SU Op & 10 & Male & 38 & Night & 65 & 92 & & 23.08 & No fatigue occurred \\
\hline & & & & Morning & 85 & 103 & 182 & 18.56 & No fatigue occurred \\
\hline & & & & Afternoon & 82 & 97 & & 15 & No fatigue occurred \\
\hline 7th SU Op & 11 & Male & 35 & Night & 61 & 74 & & 10.48 & No fatigue occurred \\
\hline & & & & Morning & 89 & 86 & 185 & -3.13 & No fatigue occurred \\
\hline & & & & Afternoon & 95 & 87 & & -8.89 & No fatigue occurred \\
\hline 8th SU Op & 11 & Male & 38 & Night & 86 & 99 & & 13.54 & No fatigue occurred \\
\hline & & & & Morning & 84 & 96 & 182 & 12.24 & No fatigue occurred \\
\hline & & & & Afternoon & 81 & 87 & & 5.94 & No fatigue occurred \\
\hline & Averas & Value & & & 72.69 & 86.44 & 182.75 & 12.39 & No fatigue occurred \\
\hline
\end{tabular}


Table 4. The result of operator's body temperature measurements

\begin{tabular}{|c|c|c|c|c|c|c|c|}
\hline \multirow{2}{*}{ Position } & \multirow{2}{*}{$\begin{array}{l}\text { Years of } \\
\text { Service }\end{array}$} & \multirow{2}{*}{ Sex } & \multirow{2}{*}{$\begin{array}{c}\text { Age } \\
\text { (years) }\end{array}$} & \multirow{2}{*}{ Shift } & \multicolumn{3}{|c|}{ Body Temperature } \\
\hline & & & & & Before Work & During Work & After Work \\
\hline \multirow[t]{3}{*}{ 1st CHCR Op } & 9 & Male & 29 & Night & $36.7^{\circ} \mathrm{C}$ & $36.4^{\circ} \mathrm{C}$ & $36.5^{\circ} \mathrm{C}$ \\
\hline & & & & Morning & $36.2^{\circ} \mathrm{C}$ & $36.5^{\circ} \mathrm{C}$ & $36.5^{\circ} \mathrm{C}$ \\
\hline & & & & Afternoon & $36.3^{\circ} \mathrm{C}$ & $36.2^{\circ} \mathrm{C}$ & $36.5^{\circ} \mathrm{C}$ \\
\hline \multirow[t]{3}{*}{ 2nd CHCR Op } & 3 & Male & 29 & Night & $36.2^{\circ} \mathrm{C}$ & $36.8^{\circ} \mathrm{C}$ & $36.4^{\circ} \mathrm{C}$ \\
\hline & & & & Morning & $36.4^{\circ} \mathrm{C}$ & $36.6^{\circ} \mathrm{C}$ & $36.6^{\circ} \mathrm{C}$ \\
\hline & & & & Afternoon & $36.4^{\circ} \mathrm{C}$ & $36.3^{\circ} \mathrm{C}$ & $36.5^{\circ} \mathrm{C}$ \\
\hline \multirow[t]{3}{*}{ 3rd CHCR Op } & 9 & Male & 29 & Night & $36.2^{\circ} \mathrm{C}$ & $36.5^{\circ} \mathrm{C}$ & $36.0^{\circ} \mathrm{C}$ \\
\hline & & & & Morning & $36.3^{\circ} \mathrm{C}$ & $36.4^{\circ} \mathrm{C}$ & $36.1^{\circ} \mathrm{C}$ \\
\hline & & & & Afternoon & $35.9^{\circ} \mathrm{C}$ & $36.3^{\circ} \mathrm{C}$ & $36.0^{\circ} \mathrm{C}$ \\
\hline \multirow[t]{3}{*}{ 4th CHCR Op } & 7 & Male & 27 & Night & $35.4^{\circ} \mathrm{C}$ & $36.3^{\circ} \mathrm{C}$ & $36.0^{\circ} \mathrm{C}$ \\
\hline & & & & Morning & $36.2^{\circ} \mathrm{C}$ & $36.7^{\circ} \mathrm{C}$ & $36.2^{\circ} \mathrm{C}$ \\
\hline & & & & Afternoon & $36.5^{\circ} \mathrm{C}$ & $36.1^{\circ} \mathrm{C}$ & $36.1^{\circ} \mathrm{C}$ \\
\hline \multirow[t]{3}{*}{ 5th CHCR Op } & 8 & Male & 31 & Night & $36.2^{\circ} \mathrm{C}$ & $36.5^{\circ} \mathrm{C}$ & $35.9^{\circ} \mathrm{C}$ \\
\hline & & & & Morning & $36.3^{\circ} \mathrm{C}$ & $36.3^{\circ} \mathrm{C}$ & $36.2^{\circ} \mathrm{C}$ \\
\hline & & & & Afternoon & $36.2^{\circ} \mathrm{C}$ & $36.2^{\circ} \mathrm{C}$ & $36.2^{\circ} \mathrm{C}$ \\
\hline \multirow[t]{3}{*}{ 6th CHCR Op } & 6 & Male & 28 & Night & $36.4^{\circ} \mathrm{C}$ & $36.2^{\circ} \mathrm{C}$ & $36.0^{\circ} \mathrm{C}$ \\
\hline & & & & Morning & $36.6^{\circ} \mathrm{C}$ & $36.4^{\circ} \mathrm{C}$ & $36.8^{\circ} \mathrm{C}$ \\
\hline & & & & Afternoon & $36.9^{\circ} \mathrm{C}$ & $36.6^{\circ} \mathrm{C}$ & $36.6^{\circ} \mathrm{C}$ \\
\hline \multirow[t]{3}{*}{ 7th CHCR Op } & 9 & Male & 29 & Night & $36.2^{\circ} \mathrm{C}$ & $36.2^{\circ} \mathrm{C}$ & $36.0^{\circ} \mathrm{C}$ \\
\hline & & & & Morning & $36.2^{\circ} \mathrm{C}$ & $36.4^{\circ} \mathrm{C}$ & $36.1^{\circ} \mathrm{C}$ \\
\hline & & & & Afternoon & $36.5^{\circ} \mathrm{C}$ & $36.6^{\circ} \mathrm{C}$ & $36.2^{\circ} \mathrm{C}$ \\
\hline \multirow[t]{3}{*}{ 8th CHCR Op } & 7 & Male & 29 & Night & $36.1^{\circ} \mathrm{C}$ & $36.6^{\circ} \mathrm{C}$ & $36.2^{\circ} \mathrm{C}$ \\
\hline & & & & Morning & $36.2^{\circ} \mathrm{C}$ & $36.4^{\circ} \mathrm{C}$ & $36.3^{\circ} \mathrm{C}$ \\
\hline & & & & Afternoon & $36.1^{\circ} \mathrm{C}$ & $36.7^{\circ} \mathrm{C}$ & $36.1^{\circ} \mathrm{C}$ \\
\hline \multirow[t]{3}{*}{ 1st SU Op } & 11 & Male & 59 & Night & $36.0^{\circ} \mathrm{C}$ & $36.1^{\circ} \mathrm{C}$ & $36.3^{\circ} \mathrm{C}$ \\
\hline & & & & Morning & $36.3^{\circ} \mathrm{C}$ & $36.4^{\circ} \mathrm{C}$ & $36.5^{\circ} \mathrm{C}$ \\
\hline & & & & Afternoon & $36.3^{\circ} \mathrm{C}$ & $36.6^{\circ} \mathrm{C}$ & $36.0^{\circ} \mathrm{C}$ \\
\hline \multirow[t]{3}{*}{ 2nd SU Op } & 11 & Male & 36 & Night & $36.3^{\circ} \mathrm{C}$ & $36.0^{\circ} \mathrm{C}$ & $36.3^{\circ} \mathrm{C}$ \\
\hline & & & & Morning & $36.1^{\circ} \mathrm{C}$ & $36.6^{\circ} \mathrm{C}$ & $36.5^{\circ} \mathrm{C}$ \\
\hline & & & & Afternoon & $36.4^{\circ} \mathrm{C}$ & $36.6^{\circ} \mathrm{C}$ & $36.5^{\circ} \mathrm{C}$ \\
\hline \multirow[t]{3}{*}{ 3rd SU Op } & 11 & Male & 39 & Night & $36.2^{\circ} \mathrm{C}$ & $36.8^{\circ} \mathrm{C}$ & $36.4^{\circ} \mathrm{C}$ \\
\hline & & & & Morning & $36.4^{\circ} \mathrm{C}$ & $36.6^{\circ} \mathrm{C}$ & $36.6^{\circ} \mathrm{C}$ \\
\hline & & & & Afternoon & $36.4^{\circ} \mathrm{C}$ & $36.3^{\circ} \mathrm{C}$ & $36.5^{\circ} \mathrm{C}$ \\
\hline \multirow[t]{3}{*}{ 4th SU Op } & 10 & Male & 44 & Night & $36.5^{\circ} \mathrm{C}$ & $36.6^{\circ} \mathrm{C}$ & $36.6^{\circ} \mathrm{C}$ \\
\hline & & & & Morning & $36.3^{\circ} \mathrm{C}$ & $36.8^{\circ} \mathrm{C}$ & $36.5^{\circ} \mathrm{C}$ \\
\hline & & & & Afternoon & $36.8^{\circ} \mathrm{C}$ & $36.7^{\circ} \mathrm{C}$ & $36.5^{\circ} \mathrm{C}$ \\
\hline \multirow[t]{3}{*}{ 5th SU Op } & 10 & Male & 31 & Night & $36.0^{\circ} \mathrm{C}$ & $36.0^{\circ} \mathrm{C}$ & $36.1^{\circ} \mathrm{C}$ \\
\hline & & & & Morning & $36.6^{\circ} \mathrm{C}$ & $36.1^{\circ} \mathrm{C}$ & $36.0^{\circ} \mathrm{C}$ \\
\hline & & & & Afternoon & $36.3^{\circ} \mathrm{C}$ & $36.0^{\circ} \mathrm{C}$ & $36.3^{\circ} \mathrm{C}$ \\
\hline \multirow[t]{3}{*}{ 6th SU Op } & 10 & Male & 38 & Night & $36.3^{\circ} \mathrm{C}$ & $36.4^{\circ} \mathrm{C}$ & $36.5^{\circ} \mathrm{C}$ \\
\hline & & & & Morning & $36.5^{\circ} \mathrm{C}$ & $36.7^{\circ} \mathrm{C}$ & $36.4^{\circ} \mathrm{C}$ \\
\hline & & & & Afternoon & $36.3^{\circ} \mathrm{C}$ & $36.4^{\circ} \mathrm{C}$ & $36.3^{\circ} \mathrm{C}$ \\
\hline 7th SU Op & 11 & Male & 35 & Night & $36.5^{\circ} \mathrm{C}$ & $36.5^{\circ} \mathrm{C}$ & $36.6^{\circ} \mathrm{C}$ \\
\hline & & & & Morning & $36.3^{\circ} \mathrm{C}$ & $36.2^{\circ} \mathrm{C}$ & $36.3^{\circ} \mathrm{C}$ \\
\hline & & & & Afternoon & $36.5^{\circ} \mathrm{C}$ & $36.3^{\circ} \mathrm{C}$ & $36.2^{\circ} \mathrm{C}$ \\
\hline 8th SU Op & 11 & Male & 38 & Night & $36.0^{\circ} \mathrm{C}$ & $36.4^{\circ} \mathrm{C}$ & $36.2^{\circ} \mathrm{C}$ \\
\hline & & & & Morning & $36.2^{\circ} \mathrm{C}$ & $36.4^{\circ} \mathrm{C}$ & $36.2^{\circ} \mathrm{C}$ \\
\hline & & & & Afternoon & $36.1^{\circ} \mathrm{C}$ & $36.3^{\circ} \mathrm{C}$ & $36.2^{\circ} \mathrm{C}$ \\
\hline & $\mathrm{Av}$ & e Value & & & $36.3^{\circ} \mathrm{C}$ & $36.4^{\circ} \mathrm{C}$ & $36.3^{\circ} \mathrm{C}$ \\
\hline
\end{tabular}




\section{Operator's Body Temperature}

The body temperature could be categorized as normal or not, also to categorize the workload as light, average, heavy, or extremely heavy. The results of CHCR and SU operator's body temperature measurements as in Table 4 showed that the average body temperature before work $\left(36.3^{\circ} \mathrm{C}\right)$, during work $\left(36.4^{\circ} \mathrm{C}\right)$, and after work $\left(36.3^{\circ} \mathrm{C}\right)$. From the result could be categorized as normal, and the workload was categorized as light. According to Sund-Levander (2002), human body temperature of less than $37.5^{\circ} \mathrm{C}$ means that the activity or work conducted can be categorized as light. This infers that even though the workload seemed plentiful and heavy, but if supported by a comfortable work environment, equipment and machines that facilitate the operator, and the distribution of work shifts that do not burden the operator, it will help them to stay away from fatigue and increase their productivity (Simanjuntak et al. 2021; Yasa et al. 2018; Arianto and Puspita, 2019).

To review the given workload of Coal Handling System operators in Cilacap power plant which were numerous and complex, the results of measurements and analysis showed a good sign that the workload can be categorized as light and did not cause physical fatigue. The task of CHCR Operator were to communicate and coordinate with Ship Unloader operators, Stacker Reclaimers, Bulldozer Belt Conveyors and Wheeloaders in checking coal unloading equipment, monitoring coal entrance track, and recording operating abnormalities in the Maximo system. Meanwhile, SU operator worked in unloading coal from barges to the stock piles, monitoring and recording the amount of unloaded coal, and informing the CHCR operator as well as keeping the coal from being scattered around Ship Unloader area, Chute area, and Feeder Ship Unloader area. With plentiful duties and responsibilities of CHCR and SU operators in Cilacap power plant, the company must be able to keep the working conditions favorable and make the human resources as the major factor in determining the success of company by always considering the process of distributing workload wisely, along with appropriate incentives and continuously improving company SOP, as well as safety and health at work.

\section{Managerial Implications}

The results of CHCR and SU operators' physical workload measurement through pulse and body temperature in the time range of before work, during work, in break time, and after work show that the workload of the operator is categorized as normal in physical load, and the workload level can be concluded as light. In reviewing the duties and responsibilities of CHCR and SU operators, it is very likely that operators experience physical fatigue especially for those who work in the afternoon and evening, because it's normal for a person to experience physical fatigue during such times. However, the measurement results did not support the assumption. In other words, the company has succeeded in designing and implementing the management for proportional tasks and responsibilities distribution, both in the terms of operator's number and working time, so that occupational safety and health can be achieved. Therefore, the company needs to maintain this condition through monitoring and evaluation upon operators' workload on regular and scheduled basis, so that work accidents can be minimized.

Based on the measurement results, it can be said that the physical workload problems of CHCR and SU operators which was experienced by both the company and operators is not the main cause. The detected problems include recording inaccuracies between unloading coal from barge with the availability of coal in coal silo and stock pile, and unloading coal on barge which still took a lot of time thus did not meet the company's target. The conditions were resulted in an inevitable increasing number of costs and operating abnormalities, as well as equipment damage which occurred from operator negligence. The operators also experienced lack of concentration during coal unloading.

To answer all of those problems, it is necessary for the company to carry out further investigations, because there might be other factors that possibly affect operator performance during working which eventually will cause problems in the company, such as the decreasing in operator's mental or psychological conditions, motivation, ethics, and discipline during working. 


\section{CONCLUSIONS AND RECOMMENDATIONS}

\section{Conclusions}

From the results, it can be concluded that the physical workload of Coal Handling Control Room (CHCR) operator and the Ship Unloader (SU) operator in Coal Handling System section of Cilacap Steam-Power Plant are classified as light and do not lead to work fatigue. Therefore, it can be inferred that the problems upon the company that lead to financial losses did not come from operators' excessive physical workload, As proven by the measurement results.

\section{Recomendations}

Further investigation is needed regarding the main causes of the company's losses. The operators look physically fine, but their mental condition is not confirmed yet. Therefore, further investigation regarding the workload from their mental perspective also needed. The problems faced by the company should not be related to operator's mental aspects or psychology since it can affect their productivity. The higher the work pressure received, it can directly affect a person's mental condition and ultimately interfere with their concentration. If that happens, the company will face a number of major problems. Meanwhile on the operators' side, the potential for errors will be even greater and lead to work accidents. Therefore, further researchers are suggested to conduct studies related to the workload of CHCR and SU operators from their mental perspectives.

\section{ACKNOWLEDGMENT}

The writer sends a lot of gratitude to Department of Industrial Engineering Universitas Balikpapan, PT. Sumber Segara Primadaya Cilacap, and every party who had been a big help in this research and make it come true.

\section{REFERENCES}

Arianto D, Puspita AD. 2019. Pengaruh shift kerja terhadap kinerja melalui variabel kelelahan dan beban kerja sebagai variabel intervening di PT M.I. Journal of Industrial and System Optimization 2(1):23-28.
Balfe N, Sharples S, Wilson JR. 2015. Impact of automation: measurement of performance, workload and behaviour in a complex control environment. Applied Ergonomics 47: 52-64. http://dx.doi.org/ 10.1016/j.apergo.2014.08.002

Bommer SC, Fendley M. 2018. A theoretical framework for evaluating mental workload resources in human systems design for manufacturing operations. International Journal of Industrial Ergonomics 63: 7-17. http://dx.doi.org/ 10.1016/j.ergon.2016.10.007

Christensen DG, Christensen LF. 1991. Organizational restructuring, equity valuation, and limited partnerships. Financial Review 26(4): 535-546. http://dx.doi.org/ 10.1111/j.1540-6288.1991. tb00395.x

Grandjean E. 1988. Fitting the Task tTo The Man. 4th Ededt. London: Taylor \& Francis Inc.

Hassan A, Javad JM, Abdollah G, Heidar TG, Soheila K. 2017. Heat stress level and physiological parameters among an open-pit mine workers in Razavi Khorasan, Iran. Annals of Medical \& Health Sciences Research 7(1): 54-59.

Horton LM, Nussbaum MA, Agnew MJ. 2015. Rotation during lifting tasks: Effects of rotation frequency and task order on localized muscle fatigue and performance. Journal of Occupational and Environmental Hygiene 12(2): 95-106. http:// dx.doi.org/ 10.1080/15459624.2014.957829

Isaac A, Shorrock ST, Kirwan B. 2002. Human error in European air traffic management: The HERA project. Reliability Engineering and System Safety 75(2): 257-272. http://dx.doi.org/ 10.1016/S0951-8320(01)00099-0

Ivarsson A, Eek F. 2016. The relationship between physical workload and quality within line-based assembly. Ergonomics 59(7): 913-923. http:// dx.doi.org/ 10.1080/00140139.2015.1105303

Jex SM. 1998. Stress and Job Performance: Theory, Research aAnd Implications fFor Managerial Practice. California: SAGE Publications.

Kahya E. 2007. The effects of job characteristics and working conditions on job performance. International Journal of Industrial Ergonomics 37(6): 515-523. http://dx.doi.org/ 10.1016/j. ergon.2007.02.006

LePine JA, Podsakoff NP, LePine MA. 2005. A metaanalytic test of the challenge Stressor-hindrance stressor framework: An explanation for inconsistent relationships among Stressors and performance. Academy of Management Journal 
48(5): 764-775. http://dx.doi.org/ 10.5465/ AMJ.2005.18803921

Lindblom J, Thorvald P. 2014. Towards a framework for reducing cognitive load in manufacturing personnel. Advances in Cognitive Engineering and Neuroergonomics 11: 233-244.

Madeleine P. 2010. On functional motor adaptations: From the quantification of motor strategies to the prevention of musculoskeletal disorders in the neck-shoulder region. Acta Physiologica 199: 1-46. http://dx.doi.org/ 10.1111/j.17481716.2010.02145.x

Manuaba M. 1998. Bunga Rampai Ergonomi. Denpasar: Udayana University Press.

Mutia M. 2016. Pengukuran beban kerja fisiologis dan psikologis pada operator pemetikan teh dan operator produksi teh hijau di PT Mitra Kerinci. Jurnal Optimasi Sistem Industri 13(1): 503-517. http://dx.doi.org/ 10.25077/josi.v13.n1.p503517.2014

Nurmianto E. 1996. Ergonomi, Konsep Dasar dDan Aplikasinya. Surabaya: PT. Guna Widya.

Rusnock CF, Borghetti BJ. 2018. Workload profiles: A continuous measure of mental workload. International Journal of Industrial Ergonomics 63: 49-64. http://dx.doi.org/10.1016/j. ergon.2016.09.003

Schor JB. 1991. The Overworked American: The Unexpected Decline of Leisure. New York: Basic Books.

Simanjuntak DCY, Mudrika AH, Tarigan AS. 2021. Pengaruh stres kerja, beban kerja, lingkungan kerja terhadap kinerja karyawan PT. Jasa Marga (persero) Tbk Cabang Belmera. Jurnal Indonesia Sosial Teknologi 2(3): 353-365.
Sund-Levander M, Forsberg C, Wahren LK. 2002. Normal oral, rectal, tympanic and axillary body temperature in adult men and women: A systematic literature review. Scandinavian JournalofCaring Sciences 16(2): 122-128.http:// dx.doi.org/ 10.1046/j.1471-6712.2002.00069.x

Tarwaka, Bakri SH, Sudiajeng L. 2004. Ergonomi Untuk Keselamatan, Kesehatan Kerja dan Produktivitas. Pertama. Surakarta: Uniba Press.

Tustin AW, Lamson GE, Jacklitsch BL, Thomas BL, Arbury SB, Cannon D, Gonzales RG, Hodgnos MJ. 2018. Evaluation of occupational exposure limits for heat stress in outdoor workers - United States, 2011-2016. MMWR. Morbidity and Mortality Weekly Report 67(26): 733-737. http:// dx.doi.org/ 10.15585/mmwr.mm6726a1

VidulichMA,Tsang PS. 2015. The confluence of situation awareness and mental workload for adaptable human-machine systems. Journal of Cognitive Engineering and Decision Making 9(1): 95-97. http://dx.doi.org/ 10.1177/1555343414554805

Yan S, Tran CC, Chen Y, Tan K, Habiyaremye JC. 2017. Effect of user interface layout on the operators' mental workload in emergency operating procedures in nuclear power plants. Nuclear Engineering and Design 322: 266-276. http:// dx.doi.org/ 10.1016/j.nucengdes.2017.07.012

Yasa IMA, Adiputra N, Sutarja IN. 2018. Redesain alat kerja pengamplas dan hand stretching dapat menurunkan beban kerja dan nyeri muskuloskeletal serta meningkatkan produktivitas kerja pekerja bengkel bagian proses pengamplasan di desa tengkudak tabanan. Jurnal Ergonomi Indonesia 4(2): 1-8. 